\title{
Gaya Hidup sebagai Faktor Risiko Diabetes Melitus Tipe 2
}

\author{
Made K. Murtiningsih. ${ }^{1}$ Karel Pandelaki. $^{2}$ Bisuk P. Sedli ${ }^{2}$
}

\author{
${ }^{1}$ Program Studi Pendidikan Dokter Fakultas Kedokteran Universitas Sam Ratulangi, Manado, \\ Indonesia \\ ${ }^{2}$ Bagian Ilmu Penyakit Dalam Fakultas Kedokteran Universitas Sam Ratulangi, Manado, \\ Indonesia \\ Email: madekheren11@gmail.com
}

\begin{abstract}
Type 2 diabetes mellitus (T2DM) is a metabolic disease caused by insulin resistance and beta cell dysfunction. It is ranked as the seventh of top 10 causes of death worldwide, and the highest prevalence of cases is T2DM. The dominant lifestyle that triggers T2DM is diet and physical inactivity. This study was aimed to determine whether lifestyle was a risk factor of T2DM. This was a literature review study using two databases, namely Pubmed and Google Scholar. The keywords used were "lifestyle risk factors and type 2 diabetes mellitus". There were 10 literatures obtained based on inclusion and exclusion criteria. The results showed that lifestyle such as unhealthy eating pattern and less physical activity significantly influence the risk factors of T2DM. In conclusion, lifestyles such as unhealthy foods and less physical activity are at high risk of suffering from T2DM.
\end{abstract}

Keywords: risk factors, lifestyle, type 2 diabetes mellitus (T2DM)

\begin{abstract}
Abstrak: Diabetes melitus tipe 2 (DMT2) merupakan penyakit metabolisme yang disebabkan karena resistensi insulin dan disfungsi sel beta pankreas. DM berada diperingkat ke tujuh sebagai 10 penyakit penyebab kematian di dunia, denganDMT2 sebagai prevalensi kasus tertinggi. Pola hidup yang dominan menjadi pencetus DMT2 ialah pola makan dan aktivitas fisik. Penelitian ini bertujuan untuk mengetahui gaya hidup sebagai faktor risiko DMT2. Jenis penelitian ialah literature review. Pencarian data menggunakan dua database yaitu Pubmed dan Google Scholar. Dengan kata kunci yaitu "faktor risiko gaya hidup dan diabetes melitus tipe 2". Setelah diseleksi, didapatkan 10 literatur berdasarkan kriteria inklusi dan eksklusi. Hasil penelitian mendapatkan bahwa gaya hidup seperti pola makan yang tidak sehat dan pola aktivitas fisik kurang secara bermakna berpengaruh terhadap terjadinya faktor risiko DMT2. Simpulan penelitian ini ialah gaya hidup dengan mengonsumsi makanan tidak sehat dan aktivitas fisik yang kurang memiliki risiko tinggi mengalami DMT2.
\end{abstract}

Kata kunci: faktor risiko, gaya hidup, diabetes melitus tipe 2 (DMT2)

\section{PENDAHULUAN}

Diabetes melitus (DM) adalah penyakit kronis yang terjadi ketika pankreas tidak dapat memroduksi insulin yang cukup atau ketika tubuh tidak dapat menggunakan insulin yang dihasilkan secara efektif. Insulin adalah hormon yang mengatur gula darah. Hiperglikemia atau gula darah yang meningkat, merupakan efek umum dari diabetes tidak terkontrol yang menyebabkan kerusakan serius pada banyak sistem tubuh, khususnya saraf dan pembuluh darah. ${ }^{1}$

Diabetes melitus berada diperingkat ke7 sebagai 10 penyakit penyebab kematian di dunia; 90\%-95\% kasus merupakan DM tipe 2 (DMT2). Internasional Diabetes Federation (IDF) memperkirakan bahwa Indonesia berada di peringkat ke-6 dengan jumlah penyandang diabetes yang berusia 20-79 tahun sekitar 10,2 juta orang pada tahun 2017 dan diperkirakan meningkat menjadi 16,7 juta orang pada tahun $2045 .^{2}$ 
Penyakit DMT2 merupakan penyakit metabolisme yang disebabkan karena resistensi insulin dan disfungsi sel beta pankreas. Pola hidup yang dominan menjadi pencetus DMT2 ialah pola makan dan aktivitas fisik. Tingginya jumlah penyandang DMT2 antara lain disebabkan oleh perubahan gaya hidup masyarakat serta kesadaran untuk melakukan deteksi dini penyakit DM, kurangnya aktivitas fisik, dan pengaturan pola makan yang salah. ${ }^{3}$

Pengetahuan yang kurang tentang gaya hidup mengakibatkan masyarakat baru sadar terkena penyakit DM setelah mengakibatkan sakit parah. ${ }^{3}$ Berdasarkan latar belakang yang telah dikemukakan maka penulis tertarik untuk menelusuri mengenai gaya hidup sebagai faktor risiko DMT2.

\section{METODE PENELITIAN}

Penelitian ini dilakukan pada periode September hingga Desember 2020 melalui media daring dan luring Jenis penelitian ialah suatu literature review. Penelusuran literatur dilakukan melalui database Pubmed dan Google Scholar dengan kata kunci faktor risiko gaya hidup dan diabetes mellitus tipe 2 dan kata kunci dalam Bahasa Inggris (risk factors life style and type 2 diabetes mellitus).

Kriteria inklusi penelitian ini ialah pengaruh gaya hidup pada pola makan tidak sehat dan aktivitas fisik kurang pada kejadian DMT2. Kriteria eksklusi yakni gaya hidup sehat seperti vegetarian, konsumsi makanan bergizi, olahraga teratur dan literatur yang tidak tersedia fulltext.

\section{HASIL PENELITIAN}

Berdasarkan hasil penelusuran di Pubmed dan Google Scholar dengan kata kunci faktor resiko gaya hidup dan diabetes mellitus tipe 2 dan kata kunci dalam Bahasa Inggris (risk factors life style and type 2 diabetes mellitus) didapatkan sebanyak 9850 artikel Google Scholar dan 2.500 artikel Pubmed $(\mathrm{n}=12.350)$ yang sesuai dengan kata kunci tersebut. Metode penelitian yang didapatkan ialah cross sectional, retrospektif, dan case control. Tahun publikasi literatur ialah 2014-2020 serta berbahasa Inggris dan Indonesia.

Berdasarkan hasil pencarian literatur diperoleh sebanyak 9.850 artikel Google Scholar dan 2.500 artikel Pubmed $(\mathrm{n}=$ 12.350) yang sesuai kata kunci tersebut. Hasil skrining berdasarkan judul sesuai dengan topik literature review mendapatkan 20 artikel $(n=20)$. Selanjutnya 20 jurnal dilakukan asesmen kelayakan full text berdasarkan kriteria inklusi dan ekslusi dan didapatkan 10 artikel $(n=10)$. Artikel yang didapat kemudian diseleksi kembali dan diuraikan pada diagram prisma yang dianalisis secara mendalam

Tabel 1. Hasil studi seleksi literatur

\begin{tabular}{|c|c|c|c|c|}
\hline No & $\begin{array}{l}\text { Penulis jurnal } \\
\text { (Tahun) }\end{array}$ & $\begin{array}{c}\text { Populasi dan } \\
\text { tempat } \\
\text { penelitian }\end{array}$ & $\begin{array}{c}\text { Jenis } \\
\text { penelitian }\end{array}$ & $\begin{array}{c}\text { Hasil } \\
\text { penelitian }\end{array}$ \\
\hline 1. & $\begin{array}{l}\text { Hariawan } \mathrm{H} \text { et al, } \\
2019 .{ }^{4}\end{array}$ & $\begin{array}{l}\text { Seluruh pasien rawat } \\
\text { jalan yang terdiagnosis } \\
\text { DM lebih dari } 10 \text { tahun } \\
\text { di RS Provinsi NTB }\end{array}$ & $\begin{array}{l}\text { Retro- } \\
\text { spective } \\
\text { study }\end{array}$ & $\begin{array}{l}\text { Hasil ini membenarkan bahwa pola makan } \\
\text { tidak sehat merupakan bagian dari gaya } \\
\text { hidup yang menjadi faktor predisposisi } \\
\text { terjadinya diabetes melitus }\end{array}$ \\
\hline 2. & $\begin{array}{l}\text { Masi GNM dan } \\
\text { Mulyadi, 2017. }\end{array}$ & $\begin{array}{l}\text { Semua pasien DMT2 di } \\
\text { Poli penyakit dalam RS } \\
\text { Pancaran Kasih Manado }\end{array}$ & $\begin{array}{c}\text { Cross } \\
\text { Sectional }\end{array}$ & $\begin{array}{l}\text { Hasil penelitian ini dapat menunjukkan } \\
\text { terdapat hubungan pola aktivitas fisik dan } \\
\text { pola makan dengan dengan kadar gula } \\
\text { darah, sehingga membenarkan adanya } \\
\text { hubungan pola aktivitas fisik dan pola } \\
\text { makan dengan kadar gula darah } \\
\text { berpengaruh terhadap kejadian DMT2 }\end{array}$ \\
\hline 3. & $\begin{array}{c}\text { Nuraini HY, } \\
\text { Supriatna, 2016. }\end{array}$ & $\begin{array}{l}\text { Sebanyak } 1299 \text { pasien } \\
\text { yang kontrol pada } \\
\text { poliklinik penyakit }\end{array}$ & $\begin{array}{c}\text { Cross } \\
\text { Sectional }\end{array}$ & $\begin{array}{l}\text { Hasil penelitian dapat menunjukkan bahwa } \\
\text { persepsi dari tiga variabel yaitu pola makan, } \\
\text { aktivitas terhadap DMT2, dan riwayat }\end{array}$ \\
\hline
\end{tabular}


dalam di RS Bunda

Margonda Depok

4. Subiyanto I, 2018. ${ }^{7} \quad$ Populasi kasus seluruh pasien penderita DMT2 dan kontrol ialah seluruh pasien yang tidak menderita DM di poliklinik RS Gatot Subroto.

5. Amanina A et al, $2015 .^{8}$

Populasi kasus penderita

DMT2 sedangkan populasi kontrolnya bukan penderita DMT2 di Puskesmas

Surakarta

6. Cahill LE et al, 2014. ${ }^{9}$

Pada 70.842 wanita dari Nurses 'Health Study dan 40.789 pria dari Health Professionals Follow-Up Study di Amerika Serikat

7. Maimunah $\mathrm{S}$ et al, Semua penderita DM $2020 .^{10}$ menjadi sampel pada kasus dan kontrol, responden 120 (60 kasus dan 60 kontrol) di RSUD DR.H.Moc

Ansari Sale

8. Yunanto KW 2017. ${ }^{11}$

Jumlah populasi (22.236)

sampel yang dipilih

minimal sebanyak 96

responden remaja di

Kecamatan Kraton

9.

Leiva AM et al, 2017. ${ }^{12}$

Sampel yang dipilih sesuai dengan 4.700 orang (4.162 normal, 538 diabetes) di universitas besar, Santiago Chili

10. Sami $\mathrm{W}$ et al, $2020 .^{13}$
Data dikumpul dari pasien yang mengunjungi Pusat Kesehatan Primer sebanyak 350 sampel di Kerajaan Arab Saudi penyakit keluarga. Hasil yang mempunyai hubungan terhadap kejadian DMT2 ialah variabel pola makan yang buruk

Case control Hasil analisis menunjukkan variabel yang didapatkan berhubungan dengan hasil penelitian pada kasus dan kontrol. Terdapat pengaruh aktivitas fisik terhadap kejadian DMT2 dan terdapat pengaruh pada pola makan terhadap kejadian DMT2.

Case control Hasil uji statistik menunjukan hubungan asupan karbohidrat dengan kejadian DMT2 di wilayah kerja Puskesmas Purwosari dan adanya hubungan asupan serat tidak baik dengan kejadian DMT2 di wilayah kerja Puskesmas Purwosari.

Cross Hasil pada kelompok responden mendapatSectional kan adanya hubungan dengan risiko terjadi DMT2 umumnya lebih kuat pada respoden yang makan gorengan di luar rumah dengan frekuensi $4 \mathrm{kali} / \mathrm{minggu}$ daripada makan gorengan di rumah dengan frekuensi yang di dapatkan $1 \mathrm{kali} /$ minggu.

Case control Didapatkan hasil bahwa pada pola makan yang tidak baik di dalamnya terdapat hubungan dan risiko terkena DM tipe 2.

Cross sectional

Cross sectional

Cross sectional Hasil uji satu sampel sikap diet keseluruhan pasien dengan DM 2 sudah cukup baik, tapi terjadi sikap positif dan sikap negatif bila dibandingkan dalam subkelompok, yang. menunjukkan bahwa pasien DM juga memiliki pengaruh sikap diet tidak tepat terhadap pilihan makanan yang tidak baik.

\section{BAHASAN}

Hasil penelitian ini menunjukkan bahwa terdapat pengaruh gaya hidup pada pola makan dan aktivitas fisik sabagai faktor risiko DMT2. Individu yang memiliki pola makan tidak teratur memiliki kadar gula darah lebih buruk dibandingkan dengan yang memiliki pola makan tidak teratur. Individu yang beraktivitas fisik sehari- 
harinya ringan memiliki risiko 2,68 kali untuk menyandang DMT2 dibandingkan dengan yang melakukan aktivitas fisik sehari-harinya sedang dan berat.

Penelitian Hariawan et $\mathrm{al}^{4}$ menyatakan bahwa pola makan tidak sehat menyebabkan ketidakseimbangan antara karbohidrat dan kandungan lain yang dibutuhkan oleh tubuh. Akibatnya kandungan gula di dalam tubuh menjadi tinggi melebihi kapasitas kerja pankreas dan berakibat terjadinya diabetes melitus.

Menurut Nuraini dan Supriatna, ${ }^{6}$ mereka yang megonsumsi setidaknya satu jenis minuman manis bersoda setiap hari akan memiliki risiko terkena DMT2 dua kali lebih besar dibandingkan dengan yang jarang mengonsumsinya. Tidak diragukan bahwa nutrisi merupakan faktor penting dalam timbulnya DMT2. Gaya hidup Westernized dan hidup santai merupakan faktor yang meningkatkan prevalensi DM. Pola makan sehari-hari yang sehat dan seimbang perlu diperhatikan, sehingga dapat mempertahankan berat badan ideal. ${ }^{6}$

Karunia $^{11}$ juga menyatakan bahwa makanan cepat saji dengan frekuensi makanan kurang dari 3 kali dalam seminggu memiliki persentase tertinggi $(61,5 \%)$ dibandingkan responden yang mengonsumsi kurang dari 1 kali seminggu. Konsumsi makanan siap saji sedikitnya seminggu sekali memiliki hubungan positif terhadap diet tinggi lemak dan peningkatan risiko timbulnya DMT2. Selain makanan cepat saji, konsumsi makanan yang digoreng dengan frekuensi makan 1 kali dalam sehari merupakan persentase tertinggi $(39,6 \%)$ dan konsumsi lebih dari 1 kali dalam sehari memiliki persentase yang cukup tinggi $(21,9 \%)$, Tingginya persentase konsumsi makanan cepat saji dapat dipengaruhi oleh lingkungan area perkotaan yang lebih maju dibandingkan area pedesaan sehingga memiliki gaya hidup modern dengan banyak menu makanan dan cara hidup yang kurang/tidak sehat. ${ }^{11}$

Cahill et $\mathrm{al}^{9}$ menunjukkan bahwa makan gorengan di luar rumah lebih kuat terjadi risiko DMT2 daripada makan gorengan di rumah. Hal ini disebabkan oleh: pertama, minyak memburuk selama menggoreng, terutama bila minyak digunakan kembali yang merupakan praktik yang mungkin lebih umum dilakukan di luar rumah daripada di rumah; kedua, frekuensi ukuran porsi seringkali lebih besar dan memiliki kandungan natrium lebih tinggi. Selain itu respoden yang mengosumsi gorengan di luar rumah atau restoran juga mengonsumsi minuman yang dimaniskan dengan gula sehingga asupan makanan dan minuman yang dikonsumsi meliputi tinggi asupan kalori, asupan natrium, dan gula.

Hasil penelitian ini juga didukung oleh penelitian Amanina et al. ${ }^{8}$ Mekanisme hubungan asupan karbohidrat dengan kejadian DMT2 ialah karbohidrat akan dipecah dan diserap dalam bentuk monosakarida, terutama gula. Penyerapan gula dapat menyebabkan peningkatan kadar gula darah dan meningkatkan sekresi insulin. Konsumsi karbohidrat berlebihan menyebabkan lebih banyak gula di dalam tubuh. Pada penyandang DMT2, jaringan tubuh tidak mampu menyimpan dan menggunakan gula, sehingga kadar gula darah dipengaruhi oleh tingginya asupan karbohidrat yang dimakan. Pada penyandang DMT2 dengan asupan karbohidrat melebihi kebutuhan, berisiko 12 kali lebih besar untuk tidak dapat mengendalikan kadar glukosa darah dibandingkan dengan penyandang yang memiliki asupan karbohidrat sesuai dengan kebutuhan. $^{8}$

Maimunah dan $\operatorname{Rahman}^{10}$ mendapatkan adanya hubungan bermakna antara pola makan dengan kejadian DMT2. Individu yang mempunyai pola makan buruk berisiko 3,8 lebih besar terkena DM dibandingkan yang mempunyai pola makan baik. Bila seseorang menjaga pola makan dengan baik seperti konsumsi rendah gula dan tinggi serat (lebih banyak makan buah dan sayuran), hal ini dapat memperkecil risiko menyandang DMT2. Kementerian Kesehatan RI juga menyebutkan bahwa konsumsi makanan yang tidak seimbang, tinggi gula, dan rendah serat juga merupakan faktor risiko DM. ${ }^{10}$

Penelitian oleh Sami et al ${ }^{13}$ di Saudi Arabia menyatakan bahwa peran sikap 
budaya dan perilaku terhadap makanan dalam pengelolaan diabetes tidak dapat diabaikan, karena sikap penyandang DM terhadap makanan dipengaruhi oleh budaya yang kuat. Kebanyakan penyandang menyatakan bahwa pemilihan makanan, dampak kesehatannya, pilihan sehat, pembatasan makanan, dan kategorisasi makanan tidak penting bagi mereka. Faktor penghalang pada budaya di Saudi Arabia terhadap pemilihan makanan dan konsumsi serta dampak kesehatannya juga telah didukung oleh penelitian lokal. Mayoritas pasien menyatakan tidak suka makan makanan diet, juga tidak suka menjauhi makanan mengandung gula, serta masih mengonsumsi daging merah, nasi, produk susu, dan junk food. Sebagian besar pasien dalam penelitian tersebut tidak menyadari kandungan kalori dalam makanan yang dikonsumsi. ${ }^{13}$

Sehubungan dengan pengaruh pola aktivitas fisik terhadap DMT2, Masi dan Mulyadi $^{5}$ melaporkan bahwa aktivitas fisik yang kurang menyebabkan resistensi insulin pada DMT2. Menurut Indonesian Diabetes Association, selain faktor genetik, DMT2 juga dapat dipicu oleh lingkungan yang menyebabkan perubahan gaya hidup tidak sehat, seperti makan berlebihan (berlemak dan kurang serat), kurang aktivitas fisik dan stres. DMT2 sebenarnya dapat dikendalikan atau dicegah melalui gaya hidup sehat, seperti makanan sehat dan aktivitas fisik teratur. ${ }^{5}$ Hal ini didukung oleh penelitian Leiva et $\mathrm{al}^{12}$ yang menyatakan bahwa aktivitas fisik dan gaya hidup menetap (waktu duduk yang lama) berkontribusi terhadap risiko DMT2 baik pada individu yang tidak aktif secara fisik dan mereka dengan gaya hidup yang tidak banyak bergerak ( $\geq 4$ jam sehari).

Menurut Subiyanto, ${ }^{7}$ aktivitas fisik sangat erat berhubungan dengan penyakit metabolik karena bila seseorang tidak melakukan aktivitas fisik 30 menit perhari atau 3 kali dalam seminggu, maka akan terjadi penumpukan lemak dalam tubuh dan insulin tidak mencukupi untuk mengubah glukosa menjadi energi yang berakibat terjadinya DMT2 dengan peningkatan glukosa darah. Sebagian besar responden mengakui kurang melakukan aktivitas fisik sehari-hari karena kesibukan pekerjaan yang hanya duduk di kantor dan hanya menggerakkan otot tangan serta kurang melakukan aktivitas fisik ("malas bergerak").

Putra $^{14}$ menyatakan bahwa aktivitas fisik seperti kegiatan sehari-hari dan latihan jasmani secara teratur yang dilakukan 3-4 kali seminggu selama kurang lebih 30 menit merupakan salah satu langkah dalam pengelolaan DMT2. Dikatakan bahwa aktivitas fisik ringan antara lain hanya berjalan santai, bermain golf, berjalan kaki ke pasar (tidak mengunakan mobil), banyak duduk di depan komputer, dan menonton televisi dengan waktu yang lama. Sebagai aktivitas fisik sedang yaitu termasuk berkebun, berjalan kaki cepat, bersepeda santai, dan berenang biasa. Pada aktivitas fisik berat yang sering dilakukan yaitu olahraga sepak bola, menggunakan tangga, jogging, berenang berat (dalam perlombaan), serta bersepeda dengan lintasan menanjak. Intensitas aktivitas fisik sedang dan berat perlu ditingkatkan untuk mencegah terjadinya faktor risiko DMT2 dan untuk aktivitas fisik ringan sebisanya dapat dihindari. ${ }^{14}$

Sejalan dengan penelitian Sinaga $^{15}$ dikatakan bahwa denyut nadi maksimal yang harus dicapai selama aktivitas fisik dengan menggunakan rumus denyut nadi maksimal ialah 220 dikurangi umur. Target denyut nadi maksimal pada aktivitas fisik yang harus dicapai antara 60\%-79\% dari nilai maksimal. Denyut nadi melebihi $79 \%$ dapat membahayakan kesehatan.

\section{SIMPULAN}

Gaya hidup mengonsumsi makanan seperti fast food, junk food, karbohidrat tinggi, dan minuman manis serta gaya hidup dengan aktivitas fisik kurang dan duduk berjam-jam memiliki risiko tinggi mengalami DMT2.

\section{Konflik Kepentingan}

Penulis menyatakan tidak terdapat konflik kepentingan dalam studi ini.

\section{DAFTAR PUSTAKA}

1. Meuraxa CZ. Gambaran pengetahuan pasien 
diabetes melitus tipe II tentang resiko terjadinya ulkus diabetikum di RSUP. H. Adam Malik [Skripsi]. Medan: Universitas Sumatera Utara; 2017.

2. International Diabetes Federation (IDF). 2014. IDF Diabetes Atlas. Available from: https://idf.org/e-library/epidemiologyresearch/diabetes-atlas.html

3. Azriful, Nildawati, Habibi, Juddin DR. Hubungan tingkat pengetahuan faktor risiko DM dengan status DM pada pegawai Negeri Sipil UIN Alauddin Makassar. Al-Sihah. 2018;10(1):63-71.

4. Hariawan H, Fathoni A, Purnamawati D. Hubungan gaya hidup (pola makan dan aktivitas fisik) dengan kejadian diabetes melitus di Rumah Sakit Umum Provinsi NTB. Jurnal Keperawatan terpadu. 2019; 1(1):1-6.

5. Masi GNM, Mulyadi. Hubungan pola aktivitas fisik dan pola makan dengan kadar gula darah Pada Pasien Diabetes Melitus tipe II di Poli Penyakit Dalam Rumah Sakit Pancaran Kasih GMIM Manado. eJournal Keperawatan. 2017;5(1).

6. Nuraini HY, Supriatna R. Hubungan pola makan, aktivitas fisik dan riwayat penyakit keluarga terhadap diabetes melitus tipe 2 . Jurnal Ilmu Kesehatan Masyarakat. 2019; 5(1):5-13.

7. Subiyanto I. Pengaruh gaya hidup terhadap kejadian DM tipe 2 di Poliklinik Penyakit Dalam RSPAD Gatot Subroto Jakarta Pusat Tahun 2017. JIKO (Jurnal Ilm Keperawatan Orthop). 2018:2(2).

8. Amanina A, Raharjo B, Sewtyo FN. Hubungan asupan karbohidrat dan serat dengan kejadian dm Tipe II di wilayah kerja Puskesmas Purwosari Surakarta [Artikel
Penelitian]. Surakarta: Universitas Muhammadiyah Surakarta; 2015.

9. Cahill LE, Pan A, Chiuve SE, Sun Q, Fried-food consumption and risk of type 2 diabetes and coronary artery disease: a prospective study in 2 cohorts of US women and men. Am J Clin Nutr. 2014;100(2):667-75.

10. Maimunah S, Asrinawaty, Rahman E. Pengaruh faktor aktifitas fisik, genetik, dan pola makan terhadap kejadian diabetes melitus tipe 2 di RSUD DR. H. Moch Ansari Saleh Banjarmasin tahun 2020, 2020. Available from: http://eprints.uniska-bjm. ac.id/3130/1/ARTIKEL \%20SITI\%20 MAIMUNAH $\% 2016070405 \% 5 B 49 \% 5$ D.pdf

11. Yunanto KW. Pengetahuan, sikap dan tindakan terhadap pola hidup terkait faktor risiko diabetes melitus tipe 2 pada remaja di Kecamatan Kraton Yogyakarta [Skripsi]. Yogyakarta: Universitas Sanata Dharma; 2017.

12. Leiva AM, Martinez MA, Petermann F, GarridoMéndez A, Poblete-Valderrama F, DíazMartínez X, Risk factors associated with type 2 diabetes in Chile. 2017. Available from:http://dx.doi.org/10.4067/s003498872018001201415

13. Sami W, Alabdulwahhab KM, Ab Hamid MR, Alasbali TA, Al Alwadani F, Ahmad MS. Dietary attitude of adults with type 2 diabetes mellitus in the Kingdom of Saudi Arabia: A cross-sectional study. Medicina (Kaunas). 2020;56(2):91.

14. Putra IWA, Berawi K. Empat pilar penatalaksanaan pasien diabetes mellitus tipe 2 . Majority. 2015;4(9):8-12.

15. Sinaga RN. Diabetes mellitus dan olahraga. J Ilmu Keolahragaan. 2016;15(2):21-9. 